\title{
PENINGKATAN KEMAMPUAN PENGELOLAAN EMOSI KORBAN PERCERAIAN BERBANTUAN BIMBINGAN PRIBADI-SOSIAL DENGAN TEKNIK SIMULASI SISWA SMP NEGERI 1 TAKERAN KABUPATEN MAGETAN
}

\author{
Afifatul Fitria Bahiroh \\ Vitalis Djarot Sumarwoto
}

\begin{abstract}
Abstrak
Berdasarkan hasil pengamatan dan catatan konselor sekolah, diperoleh informasi bahwa di SMP Negeri 1 Takeran Kabupaten Magetan khususnya siswa kelas VIII, menunjukkan kurang mampu mengelola emosinya. Penyebab yang paling dirasakan adalah karena latar belakang perceraian orang tua. Akibatnya, kebanyakan siswa tersebut merasa minder, kurang mampu memotivasi diri sendiri, tingkat kecemasan yang berlebihan, dan kurang mampu bangkit dari perasaan-perasaan yang menekan. Kemampuan pengelolaan emosi merupakan penunjang dari keberhasilan siswa dalam bersosialisasi dan mengoptimalkan kemampuannya, sehingga ada alasan perlu ditingkatkan. Harapan dalam penelitian ini siswa lebih mampu memotivasi diri, bertahan menghadapi frustasi, mampu mengendalikan dorongan hati, tidak melebih-lebihkan kesenangan, mampu mengatur suasana hati dan berempati.

Tujuan penelitian ini untuk mengetahui peningkatan kemampuan pengelolaan emosi korban perceraian melalui bimbingan pribadi-sosial dengan teknik simulasi siswa kelas VIII SMP Negeri 1 Takeran Kabupaten Magetan. Sampel penelitian ditetapkan dengan teknik purposive sampling, yaitu siswa korban dari orang tuanya bercerai, sebanyak 16 siswa, dan yang terindikasi belum mampu mengelola emosi yang disebabkan perceraian orang tua sebanyak 5 siswa. Penentuan jumlah sampel penelitian mengacu pada hasil observasi peneliti dan catatan hasil analisis data kepribadian dari konselor sekolah. Pengumpulan data menggunakan teknik angket. Rancangan penilitian ini menggunakan pra eksperimental, dengan desain one-group pretest-post test. Analisis data penelitian mengunakan teknik statistik, dengan rumus $t$-score.

Hasil penelitian menunjukkan bahwa ada peningkatan kemampuan mengelola emosi korban perceraian orang tua melalui bimbingan pribadi-sosial dengan teknik simulasi pada siswa kelas VIII SMP Negeri 1 Takeran Kabupaten Magetan.
\end{abstract}

Kata Kunci: Pengelolaan Emosi Korban Perceraian, Bimbingan Pribadi-Sosial, Teknik Simulasi

* Afifatul Fitria Bahiroh adalah Mahasiswa Program Studi Bimbingan dan Konseling Fakultas Ilmu Pendidikan IKIP PGRI Madiun.

** Vitalis Djarot Sumarwoto adalah Dosen Program Studi Bimbingan dan Konseling Fakultas Ilmu Pendidikan IKIP PGRI Madiun. 


\section{Pendahuluan}

Pendidikan adalah usaha sadar untuk meneruskan dan mentransfer ilmu pengetahuan dari generasi satu ke generasi berikutnya. Pendidikan bukan sematamata menjadi tanggung jawab sekolah, tetapi juga merupakan tanggung jawab pemerintah, keluarga, dan masyarakat. Perkembangan pendidikan di Indonesia pada dasarnya tidak dapat dilepaskan dengan arus globalisasi yang semakin kuat, yang antara lain ditandai dengan perkembangan ilmu pengetahuan dan teknologi pun semakin meningkat. Dampak yang dirasakan, baik secara langsung atau tidak langsung, adalah munculnya persaingan dalam berbagai bidang kehidupan, tanpa kecuali dalam bidang pendidikan. Untuk menghadapi fenomena tersebut di atas, dibutuhkan sumber daya manusia yang berkualitas, yang pada hakikatnya dapat disiapkan melalui proses pendidikan dalam keluarga. Syaiful Bahri Djamarah (2004:16) mengartikan keluarga sebagai institusi yang terbentuk karena ikatan perkawinan, yang didalamnya hidup bersama pasangan suami istri (pasutri). Pasangan suami istri (pasutri) membentuk keluarga dengan tujuan memperoleh kebahagiaan dan kesejahteraan lahir dan batin.

Ditinjau dari keberadaan keluarga, maka dapat dibedakan menjadi keluarga utuh dan keluarga tidak utuh. Keluarga utuh adalah keluarga yang terdiri dari pasangan suami-isteri, dan anak-anak yang dilahirkan, dan yang tinggal satu rumah. Keluarga tidak utuh dalam penelitian ini terbatas pada salah satu dari anggotanya tidak lagi tinggal dalam satu rumah, antara lain karena perceraian, yang sekaligus menjadi obyek material penelitian. Dampak yang timbul akibat korban perceraian orang tua, sesuai dengan hasil analisis konselor sekolah dan hasil observasi peneliti adalah siswa kurang mampu mengelola emosinya.

Bertolak dari uraian di atas peneliti memandang bahwa kekurang-mampuan siswa dalam mengelola emosi harus dinyatakan sebagai masalah. Setiap masalah perlu segera dicarikan solusinya. Salah satu solusi yang ditawarkan adalah dengan memberikan bimbingan sosial-pribadi. Keunggulan bimbingan sosial-pribadi sebagai solusi meningkatkan dalam mengelola emosi korban perceraian orang tua siswa adalah sebagai berikut: (a) tujuan utama bimbingan sosial-pribadi adalah merupakan bantuan untuk memecahkan masalah-masalah yang berkaitan dengan hubungan dengan sesama manusia yang terdapat di sekitar, (b) bimbingan sosial pribadi diarahkan untuk memantapkan kepribadian dan mengembangkan kemampuan siswa dalam mengatasi masalah-masalah yang dirasakan, dan (c) bimbingan sosial-pribadi diberikan untuk menciptakan lingkungan yang kondusif, mengembangkan pemahaman diri dan sikap-sikap yang positif. Jadi apabila siswa mengikuti layanan bimbingan sosial-pribadi dilakukan dengan tepat dan serius, maka pada akhirnya dalam diri siswa timbul suatu kemampuan untuk meningkatkan pengelolaan emosinya. 


\section{Kajian Pustaka}

\section{Kemampuan Pengelolaan Emosi Korban Persecaraian \\ a. Pengertian Kemampuan Pengelolaan Emosi}

Peter Solovey (dalam Khusnul Azizah, 2009: 1) menyatakan bahwa pengelolaan emosi merupakan kesadaran diri dalam membantu, dan mengungkapkan perasaan.

Menurut Kamus Besar Bahasa Indoensia (1995) pengelolaan emosi diartikan sebagai suatu proses, cara dan perbuatan mengendalikan, menyelenggarakan, mengurus dan mengatur kehidupan perasaan yang muncul pada diri seseorang.

Goleman (1977) menegaskan pengelolaan emosi didefinisikan kemampuan untuk mengatur perasaan, menenangkan diri, melepaskan diri dari kecemasan, kemurungan, atau ketersinggungan, dengan tujuan untuk keseimbangan emosi (T. Hermaya, 2009: 36).

Berdasarkan beberapa pengertian di atas maka hakikat pengelolaan emosi adalah cara yang ditempuh oleh seseorang untuk menunjukkan kemampuannya dalam mengendalikan, menyelenggarakan, mengurus dan mengatur kehidupan perasaannya, menenangkan diri, dan melepaskan diri dari kecemasan dengan tujuan memberikan keseimbangan emosi.

\section{b. Pengertian Korban Perceraian}

Adrian (dalam Putri Rosalia Ningrum, 2013: 71) menyatakan bahwa inti dari pengertian korban perceraian adalah anak yang merasakan tanda kematian keutuhan keluarganya, rasanya separuh diri anak telah hilang, hidup tak akan sama lagi setelah orangtua mereka bercerai dan mereka harus menerima kesedihan dan perasaan kehilangan yang mendalam, perasaan kehilangan, penolakan dan ditinggalkan akan merusak kemampuan anak berkonsentrasi di sekolah.

Depdiknas (2010) menjelaskan bahwa istilah korban perceraian terbentuk dua kata: "korban" (2010: 595) dan “perceraian" (2010: 209). Inti kedua kata tersebut adalah perpisahan atau perpecahan antara suami dan isteri atau ayah dan ibu dari ikatan pernikahan yang memberi dampak penderitaan anak-anak yang dilahirkannya.

Atas dasar beberapa pendapat tersebut dapat dirumuskan bahwa pada dasarnya korban perceraian dapat diartikan sebagai kesedihan dan perasaan kehilangan yang timbul dalam diri anak karena orang tua (ayahibu atau suami-isteri memisahkan diri dari ikatan perkawinan karena sesuatu alasan, yang memberi dampak kurang baik terhadap kehidupan perasaaan anak yang dilahirkannya. 


\section{c. Pengertian Kemampuan Pengelolaan Emosi Korban Perceraian}

Bertolak dari uraian di atas maka kemampuan pengelolaan emosi korban perceraian dapat diartikan sebagai kesanggupan seseorang untuk menunjukkan kemampuannya dalam mengendalikan, menyelenggarakan, mengurus dan mengatur kehidupan perasaannya, menenangkan diri, dan melepaskan diri dari kecemasan. Tujuan yang ingin dicapai adalah mencari keseimbangan perasaan dan menghindari dampak yang kurang menyenangkan dalam hidupnya.

\section{Bimbingan Pribadi-Sosial}

a. Pengertian Bimbingan Pribadi-sosial

Achmad Juntika Nurihsan (2009: 15) menyatakan bimbingan pribadisosial merupakan bimbingan untuk membantu para individu dalam menyelesaikan masalah-masalah sosial pribadi.

Winkel dan Sri Hastuti (2007: 118) mendefiniskan bimbingan pribadi-sosial adalah layanan yang bersifat membantu individu untuk menghadapi keadaan batinnya sendiri, mengatur dirinya sendiri dalam kerohanian, perawatan jasmani. Bantuan dalam bimbingan tersebut untuk membina hubungan kemanusiaan dengan sesama di berbagai lingkungan.

Beberapa pengertian bimbingan pribadi-sosial tersebut diatas pada hakikatnya memberi petunjuk bahwa bimbingan pribadi-sosial ditujukan kepada individu agar individu yang dibimbing mampu menghadapi dan memecahkan permasalahan sosial pribadinya seperti penyesuaian diri, menghadapi konflik dan pergaulan secara mandiri, serta mengatur dirinya sendiri dalam kerohanian.

b. Teknik Simulasi

1) Pengertian Teknik Simulasi

Pengertian teknik simulasi dalam penelitian ini mengacu pendapat dari Adams (dalam Tatiek Romlah, 2006: 118), yang menyatakan bahwa permainan simulasi merupakan permainan yang dimaksudkan untuk merefleksikan situasi-situasi yang terdapat dalam kehidupan yang sebenarnya.

2) Tujuan Permainan Simulasi

Tatiek Romlah (2006: 118-119) menegaskan tujuan permainan simulasi pada hakikatnya adalah membantu siswa untuk:

a) mempelajari pengalaman-pengalaman yang berkaitan dengan aturan-aturan sosial.

b) memperkenalkan konsep dan menanamkan pengertian tentang suatu hal. 
c) membangkitkan minat dan perhatian siswa.

3) Cara Membuat Permainan Simulasi

Tatiek Romlah (2006: 119-120) menyatakan bahwa dalam melaksanakan permainan simulasi perlu mengikuti langkah-langkah sebagai berikut :

a) Meneliti masalah, terutama masalah yang menyangkut bidang pendidikan dan sosial.

b) Merumuskan tujuan yang ingin dicapai dengan permainan itu.

c) Mengiventaris sumber yang dapat membantu menyelesaikan topik yang akan digarap.

d) Memilih situasi dalam kehidupan sebenarnya yang ada kaitannya dengan kehidupan siswa.

e) Membuat model atau skenario dari situasi yang sudah dipilih.

f) Mengidentifikasi individu-individu yang terlibat dalam permainan

g) Membuat berbagai alat permainan yang relevan untuk digunakan.

4) Cara Melaksanakan Permainan Simulasi

Pelaksanaan permainan simulasi menurut Tatiek Romlah (2006: 120) melibatkan beberapa peserta sebagai berikut:

a) Fasilitator, individu yang bertugas memimpin permainan simulasi.

b) Penulis, yaitu individu yang bertugas mencatat segala sesuatu yang terjadi selama permainan berlangsung.

c) Pemain, yaitu individu-individu yang memegang tanda bermain dan menjawab dan mendiskusikan pesan-pesan permainan simulasi.

d) Pemegang Peran, yaitu individu-individu yang berperan berbagai tokoh yang sesuai skenario.

e) Penonton, yaitu individu-individu yang menyaksikan permainan dan boleh berpartisipasi aktif selama permainan berlangsung.

Adapun hal-hal yang perlu mendapat perhatian selama permainan simulasi berlangsusng adalah:

(1) Menyediakan alat permainan beserta kelengkapannya.

(2) Fasilitator menjelaskan tujuan permainan. Dalam hal ini yang menjadi fasilitator adalah konselor.

(3) Menentukan pemain, pemegang peran, dan penulis.

(4) Menjelaskan aturan permainan.

(5) Bermain dan berdiskusi. 
(6) Menyimpulkan hasil diskusi setelah seluruh permainan selesai, dan mengemukakan masalah-masalah yang belum diselesaikan pada saat permainan berlangsung.

(7) Menutup permainan dan menentukan waktu dan tempat bermain berikutnya.

\section{Metodologi Penelitian}

Penelitian menggunakan rancangan pra-eksperimental dengan desain one-group pretest-posttest design, dengan pertimbangan karena penggunaan desain ini lebih sempurna karena menggunakan pretest dan post test sehingga dapat diketahui sejauh mana perlakuan yang diberikan meningkat (Sugiyono, 2007: 74)

Penelitian dilakukan di SMP Negeri 1 Takeran, yang beralamat di Jalan Sumbermulyo, Desa Jomblang, Kecamatan Takeran Kabupaten Magetan. SMP Negeri 1 Takeran ditetapkan sebagai tempat penelitian karena pada awal bulan Januari peneliti melakukan observasi ke beberapa SMP di sekitar wilayah kecamatan Takeran. Hasil observasi menunjukkan bahwa di sekolah tersebut banyak ditemukan fenomena masalah yang sesuai dengan karakteristik permasalahan penelitian.

Populasi penelitian adalah siswa kelas VIII SMP Negeri 1 Takeran Kabupaten Magetan, yang orang tuanya bercerai, yang berdampak pada diri siswa mengalami kesulitan mengelola emosi. Jumlah siswa kelas VIII SMP Negeri 1 Takeran Kabupaten Magetan, yang orangtuanya bercerai dan berdampak pada diri siswa mengalami kesulitan mengelola emosi adalah berjumlah 5 siswa. Penetapan populasi penelitian mengacu pada pendapat Sugiyono (2010: 117) yang menyatakan bahwa populasi adalah wilayah generalisasi yang terdiri atas: objek/subjek yang mempunyai kualitas dan karakteristik tertentu yang ditetapkan oleh peneliti untuk dipelajari dan kemudian ditarik kesimpulannya

Sampel penelitian sebanyak 5 orang siswa, dan ditetapkan dengan teknik sampling jenuh. Penetapan sampling jenuh ini mengacu pendapat Sugiyono (2010: 124), yang menyatakan bahwa sampling jenuh adalah teknik penentuan sampel bila semua anggota populasi digunakan sebagai sampel.

Teknik pengumpulan data yang digunakan dalam penelitian ini adalah angket. Menurut Suharsimi Arikunto (2010:195) inti dari angket adalah sejumlah pertanyaan tertulis yang digunakan untuk memperoleh informasi dari responden dalam arti laporan tentang pribadi, atau hal-hal yang ia ketahui. Angket dalam penelitian ini untuk mengungkap data tentang kemampuan mengelola emosi siswa setelah diberi layanan bimbingan 
pribadi-sosial. Angket disusun oleh peneliti dalam bentuk pertanyaan tertutup dengan empat jawaban alternatif yaitu: (a) selalu, (b) sering, (c) kadangkadang, (d) tidak pernah. Secara keseluruhan penyusunan angket ini mengacu pada skala likert, yaitu untuk mengungkap sikap, pendapat, dan persepsi seseorang tentang kejadian atau gejala sosial (Sugiono,2010: 135).

Validitas dan reliabilitas butir item angket ditempuh untuk menetapkan keabsahan instrumen sebagai alat pengumpul data. Uji validitas butir item angket menggunakan jasa statsitik dengan rumus bangun korelasi product moment. Rumus bangun korelasi product moment tersebut adalah sebagai berikut:

$$
r_{x y}=\frac{N \sum X Y-\left(\sum X\right)\left(\sum Y\right)}{\sqrt{\left\{N \sum X^{2}-\left(\sum X\right)^{2}\right)\left(N \sum Y^{2}-\left(\sum Y\right)^{2}\right\}}}
$$

(Sugiyono, 2010:255)

Keterangan :

$$
r_{x y}=\text { koefisien korelasi antara skor item dengan skor total }
$$

$\mathrm{X}=$ skor item

$\mathrm{Y}=$ skor total

$\mathrm{N}=$ banyaknya subyek

Kriteria penyajian dinyatakan valid apabila $\mathrm{r}$ hitung $>\mathrm{r}$ tabel dalam setiap itemnya.

Uji reliabilitas butir item angket menggunakan rumus split half Spearman Brown, yaitu sebagai berikut.

$$
r_{i}=\frac{2 r_{b}}{1+r_{b}}
$$

(Sugiyono, 2010: 185) 
Keterangan:

$r_{i}=$ realibilitas internal seluruh instrument

$r_{b}=$ korelasi product moment antara belahan pertama dan kedua

Hasil uji validitas dan reliabilitas butir item angket penelitian menunjukkan bahwa semua item angket yang disediakan dalam penelitian dinyatakan valid dan reliabel. Oleh sebab itu angket dalam penelitian ini cukup representatif untuk digunakan sebagai alat pengumpul data penelitian

Analisi data penelitian menggunakan rumus bangun t-skor sebagai berikut:

\section{$t=\frac{\sqrt{\frac{1}{3}}}{\sqrt{1}}$}

(ZainalArifin, 2012: 80)

Keterangan:

$\mathrm{Md}=$ mean dari perbedaan pre-test dengan post test (post test-pre test)

$\mathrm{xd}=$ deviasi masing - masing subyek $(\mathrm{d}-\mathrm{Md})$

$\sum \mathrm{x}^{2} \mathrm{~d}=$ jumlah kuadrat deviasi

$\mathrm{N} \quad=$ subyek pada sampel

d.b. = ditentukan dengan $\mathrm{N}-1$

\section{Hasil Penelitian}

\section{Deskripsi Data}

a. Data kemampuan pengelolaan emosi korban perceraian sebelum diberi bimbingan pribadi-sosial

Data skor angket teknik simulasi dari sampel sebanyak $\mathrm{N}=5$ siswa, dengan rentang skor angket: 20-80. Diperoleh perhitungan sebagai berikut: mean $=54$, Median $=54$, Modus $=54$, Skor terendah $=48$ dan skor tertinggi $=58$.

Mengingat data kemampuan pengelolaan emosi korban perceraian pengelolaan akan dilaporkan dalam bentuk grafik batang, maka perlu menghitung range (R) dan lebar kelas (i). Range (R) diperoleh dengan 
menari selisih antara batas atas nyata skor tertinggi dengan batas bawah skor terendah ( $(58,5-47,5=11)$. Ditentukan lebar kelas (i) adalah 3 , maka perlu menambah 1 poin pada skor tertinggi. Sehingga $\mathrm{R}$ dalam distribusi frekuensi bergolong $=(11+1): 3=4$.

Tabel 1. Distribusi Frekuensi Data Angket Kemampuan Pengelolaan Emosi Korban Perceraian Sebelum diberi Bimbingan PribadiSosial dengan dengan Teknik Simulasi

\begin{tabular}{|c|c|c|}
\hline $\begin{array}{c}\text { Interval nilai } \\
(\mathrm{i})\end{array}$ & $\begin{array}{c}\text { Titik Tengah } \\
(\mathrm{Xi})\end{array}$ & $\begin{array}{c}\text { Frekuensi } \\
(\mathrm{f})\end{array}$ \\
\hline $48-50$ & 49 & 1 \\
\hline $51-53$ & 52 & 0 \\
\hline $54-56$ & 55 & 3 \\
\hline $57-59$ & 58 & 1 \\
\hline
\end{tabular}

Bentuk grafik untuk data kemampuan mengelola emosi korban perceraian orang tua sebelum diberi bimbingan pribadi-sosial adalah sebagai berikut:

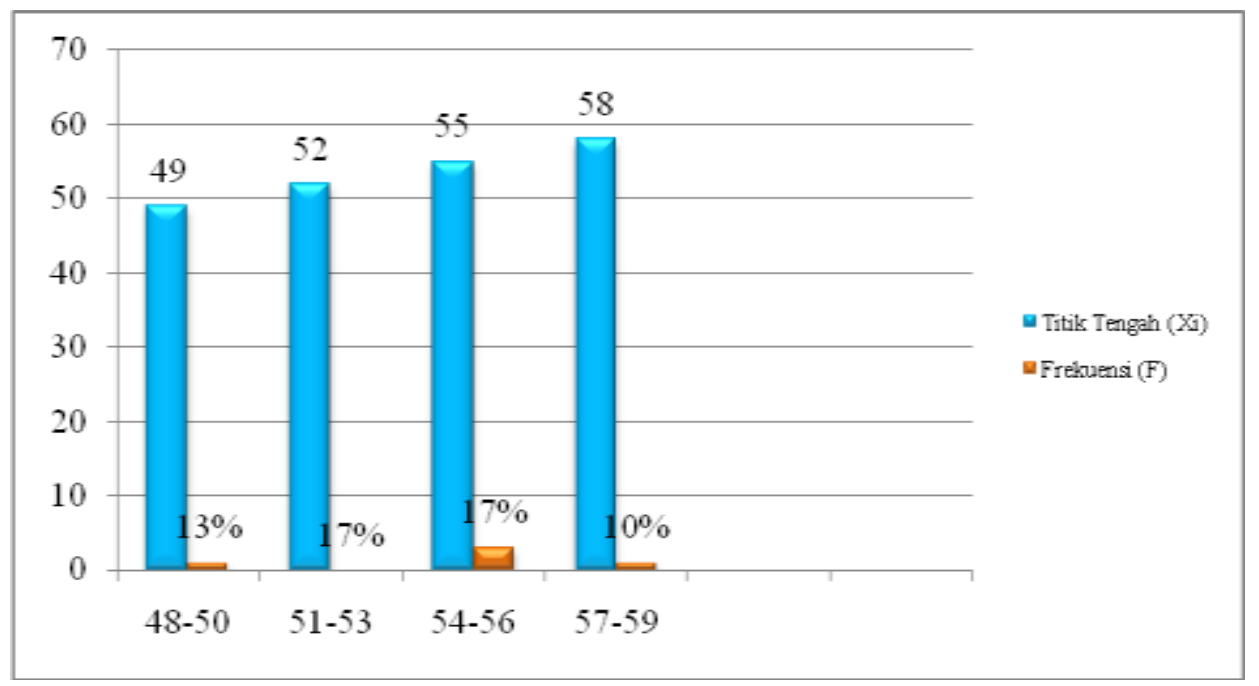

Gambar 1 Data Kemampuan Pengelolaan Emosi Korban Perceraian Sebelum diberi Bimbingan Pribadi-Sosial 
b. Deskripsi Data Pengelolaan Emosi Korban Perceraian Setelah Diberi Bimbingan Pribadi-Sosial Dengan Teknik Simulasi

Berdasarkan hasil skor angket data yang diperoleh dari sampel sebanyak $\mathrm{N}=5$ siswa, dengan rentang skor angket antara 20-80, diperoleh perhitungan sebagai berikut: mean $=61,4$, median atau nilai tengah $=62$, modus $=62$, skor terendah $=54$, dan skor tertinggi $=65$.

Mengingat bahwa data tersebut akan dilaporkan dalam grafik batang, maka langkah selanjutnya mentabulasikan data, menghitung range (R) dan lebar kelas (i). Range (R) adalah selisih batas atas nyata skor tertinggi dengan batas bawah nyata skor terendah $(65,5-53,5)=12$. Ditentukan lebar kelas (i) $=3$, jadi $\mathrm{R}$ dalam distribusi bergolong $=(12: 3)=4$ (lihat pada tabel 2).

Tabel 2: Distribusi Frekuensi Data Kemampuan Pengelolaan Emosi Korban Perceraian Sesudah Diberikan Bimbingan PribadiSosial dengan Teknik Simulasi

\begin{tabular}{|c|c|c|}
\hline $\begin{array}{c}\text { Interval nilai } \\
(\mathrm{i})\end{array}$ & $\begin{array}{c}\text { Titik Tengah } \\
(\mathrm{Xi})\end{array}$ & $\begin{array}{c}\text { Frekuensi } \\
(\mathrm{f})\end{array}$ \\
\hline $54-56$ & 55 & 1 \\
\hline $57-59$ & 58 & 0 \\
\hline $60-62$ & 61 & 2 \\
\hline $63-65$ & 64 & 2 \\
\hline
\end{tabular}

Bentuk grafik data Kemampuan Pengelolaan Emosi Korban Perceraian Sesudah Diberikan Bimbingan Pribadi-Sosial dengan Teknik Simulasi hasil distribusi nilai diatas dapat dibuat grafik seperti di bawah ini: 


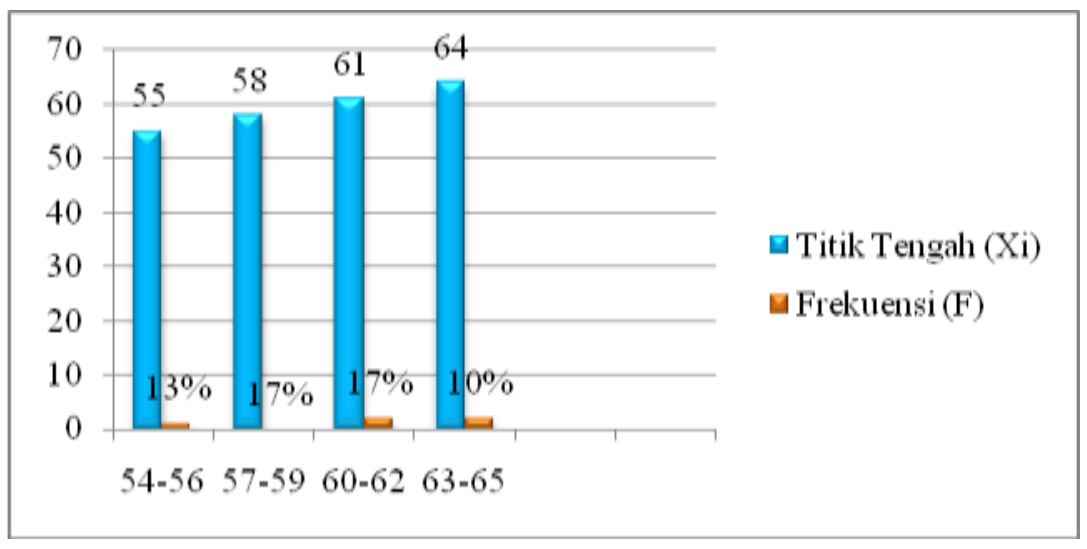

Gambar 4.2 Data Kemampuan Pengelolaan Emosi Korban Perceraian Sesudah Diberikan Bimbingan Pribadi-Sosial

\section{Hasil Analisis Data}

Hasil analisis data dapat diketahui melalui tabel persiapan menghitung peningkatan kemampuan pengelolaan emosi korban perceraian berbantuan bimbingan pribadi sosial dengan teknik simulasi, dengan rumus bangun t-scor

\begin{tabular}{|c|c|c|c|c|c|c|c|c|}
\hline No & $\begin{array}{c}\text { Pre } \\
\text { test }\end{array}$ & Post test & $\begin{array}{c}\text { Gain } \\
(\mathrm{d})\end{array}$ & $\mathrm{Xd}(\mathrm{d}-\mathrm{Md})$ & $\sum \mathrm{d}^{2}$ & $\left(\sum \mathrm{d}\right)^{2}$ & $\frac{\left(\sum \mathrm{d}\right)^{2}}{N}$ & $\sum \mathrm{X}^{2} \mathrm{~d}$ \\
\hline 1 & 56 & 62 & 26 & -306 & 99 & 324 & 64,8 & 259,2 \\
\hline 2 & 58 & 65 & 23 & -600 & 99 & 625 & 125 & 500 \\
\hline 3 & 54 & 64 & 20 & -650 & 99 & 676 & 135,2 & 540,8 \\
\hline 4 & 48 & 54 & 19 & -90 & 99 & 100 & 20 & 80 \\
\hline 5 & 54 & 62 & 22 & -380 & 99 & 400 & 80 & 320 \\
\hline
\end{tabular}




\begin{tabular}{|l|l|l|l|l|l|l|l|l|} 
& $\mathrm{x}_{1}$ & $\mathrm{x}_{2}$ & 140 & & & & & 1700 \\
\hline
\end{tabular}

Bertolak dari hasil analisis data di atas, maka diperoleh hasil perhitungan bahwa harga t-skor (t-hitung) $=1,309$. Untuk mengetahui apakah $t_{\text {hitung }}$ sebesar 1,309 signifikan atau tidak signifikan, maka perlu dikonsultasikan dengan $t_{\text {tabel }}$. Harga $t_{\text {tabel }}$ dengan d.b 4 adalah 0,741/Taraf signifikan $=5 \%$. Jadi $t_{\text {hitung }}$ lebih besar jika dibandingkan dengan $t_{\text {tabel }}(1,309>0,741)$ atas dasar taraf signifikansi sebesar 5\% (signifikan). Oleh sebab itu harus dinyatakan bahwa bimbingan pribadi-sosial dengan teknik simulasi dapat meningkatkan kemampuan pengelolaan emosi korban perceraian pada siswa SMP Negeri 1 Takeran Kabupaten Magetan.

\section{Simpulan dan saran}

Berdasarkan hasil analisis data penelitian dapat disimpulkan sebagai berikut:

1. Hipotesis yang berbunyi "ada peningkatan kemampuan pengelolaan emosi korban perceraian berbantuan bimbingan pribadi-sosial dengan teknik simulasi pada siswa kelas VII SMP Negeri 1 Takeran Kabupaten Magetan”, harus diterima.

2. Bimbingan pribadi-sosial dengan teknik simulasi dapat meningkatkan kemampuan emosional korban perceraian pada siswa kelas VII SMP Negeri 1 Takeran Kabupaten Magetan.

Atas dasar simpulan di atas dikemukakan saran bahwa pihak sekolah sebaiknya menerapkan hasil penelitian ini untuk membantu siswa yang mempunyai masalah emosi khususnya korban perceraian orang tua, atau karena korban-korban psikososial lainnya, melalui layanan bimbingan pribadi sosial berbantuan teknik simulasi. 


\section{DAFTAR PUSTAKA}

Achmad Juntika Nurihsan. 2009. Bimbingan dan Konseling Dalam Berbagai Latar Kehidupan. Bandung: PT Refika Aditama. 2011. Bimbingan dan Konseling Dalam Berbagai Latar Kehidupan. Bandung: PT Refika Aditama.

Archibald D. Hart. 2002. Menolong Anak Korban Perceraian. Melbourne: Word Publishing Dallas-London-Vancouver-Melbourne.

Daniel Goleman. 2005. Emotional Intelligence. Jakarta: PT Gramedia Pustaka Utama.

Dewa Ketut Sukardi. 2008. Pengantar Pelaksanaan Program Bimbingan dan Konseling di Sekolah. Jakarta: PT Rineka Cipta.

Dewa Ketut Sukardi dan Desak P. E. Nila Kusmawati. 2008. Proses Bimbingan Konseling di Sekolah. Jakarta: PT Rineka Cipta.

John Gottman dan Joan DeClaire. 2003. Kiat-kiat Membesarkan Anak yang Memiliki Kecerdasan Emosional. Jakarta:PT Gramedia Pustaka Utama.

Khusnul Azizah. 2009. Pengelolaan Emosi Pada Santri Huffadz. Yogyakarta: Universitas Islam Negeri Sunan Kalijaga.

Masburiyah dan Bakhtiar Hasan. 2011. Upaya Islam dalam Perkara Perceraian di Pengadilan Agama Kota Jambi. JurnalMedia Akademika (online), vol 26, No. $\quad 1, \quad$ (http://masburiyahdanbakhtiar.blogspot.com/2011/11/skalapengendalian-emosi-anger_02.html, Diunduh 15 Mei 2013).

Paul Ekman. 2008. Membaca Emosi Orang. Yogyakarta: Think Yogyakarta.

Putri Rosalia Ningrum. 2013. Perceraian Orang Tua dan Penyesuaian Diri Remaja. JurnalPsikologo (online), vol 69-79, No. 1, (http://repository.gunadarma.ac.id/bitstream/123456789/1059/1/10504177. pdf, Diunduh 15 Mei 2013).

Save M. Dagun. 2002. Psikologi Keluarga (Peranan Ayah dalam Keluarga). Jakarta: PT Rineka Cipta.

Sri Esti Wuryani Djiwandono. 2005. Konseling dan Terapi dengan Anak dan Orang Tua. Jakarta: PT Grasindo.

Sugiyono. 2007. MetodePenelitian Pendekatan Kuantitatif, Kualitatif dan $R \& D$. Bandung: Alfabeta. 2010. Metode Penelitian Pendekatan Kuantitatif, Kualitatif dan $R \& D$. Bandung: Alfabeta. 2012. Metode Penelitian Pendekatan Kuantitatif, Kualitatif dan $R \&$ D. Bandung: Alfabeta.

Suharsimi Arikunto. 2010. Prosedur Penelitian Suatu Pendekatan Praktik. Jakarta: PT Rineka Cipta.

Syaiful Bahri Djamarah. 2004. Pola Komunikasi Orang Tua dan Anak dalam Keluarga. Jakarta: PT Rineka Cipta.

Syamsu Yusuf dan Achmad Juntika Nurihsan. 2010. Landasan Bimbingan dan Konseling. Bandung: PT. Remaja Rosdakarya.

Tatiek Romlah. 2006. Teori dan Praktek Bimbingan Kelompok. Malang: Universitas Negeri Malang. 
Tohirin. 2007. Bimbingan dan Konseling di Sekolah dan Madrasah (Berbasis Integrasi). Jakarta: PT. Raja Grafindo Persada.

Vitalis Djarot Sumarwoto. 2012. Statisitk Inferensial (Statistik II). Madiun. IKIP PGRI Madiun.

W.S. Winkel dan M. M. Sri Hastuti. 2007. Bimbingan dan Konseling di Institusi Pendidikan. Yogyakarta: Media Abadi.

Zainal Arifin. 2012. Penelitian Pendidikan Metode dan Paradigm Baru. Bandung: PT. Remaja Rosdakarya.

Zainal Aqib. 2012. Ikhtisar Bimbingan dan Konseling di Sekolah. Bandung: Yrama Widya. 